\title{
The role of managers in risk management
}

\author{
Piotr Jedynak \\ Jagiellonian University in Krakow
}

Sylwia Bąk

Jagiellonian University in Krakow

\section{Introduction}

Risk management, like other management domains, has undergone significant transformations, adapting its semantic, conceptual and instrumental dimension to the changing conditions of business operations and the expectations of stakeholders. The basic directions of changes include: obtaining strategic significance through risk management in connection with its unquestionable impact on gaining a competitive advantage, creating value for stakeholders, or potential effectiveness in conditions of increasing complexity ${ }^{1}$. All these transformations generate a number of challenges for company managerial staff, and risk management itself has become one of the obligatory management functions. Therefore, it is extremely important to conduct scientific research related to the scope of responsibilities, competences and the position of managers responsible for the risk management process in the organizational structure of the enterprise.

The purpose of this text is to identify the role of a manager in contemporary enterprise risk management. The main research method was literature review as well as the analysis of professional trainings on offer that certify risk managers competences. Answers to the following questions were sought in the research process:

1 J. Calandro, A leader's guide to strategic risk management, "Strategy \& Leadership" 2015, vol. 43, no. 1, pp. 26-35; J. De Loach, The new risk imperative - an enterprise - wide approach, "Handbook of Business Strategy" 2004, vol. 5, no. 1, pp. 29-34; E. Elahi, Risk management: the next source of competitive advantage, "Foresight" 2013, vol. 15, no. 2, pp. 117-131. 
- How have managerial functions evolved in the area of risk management?

- What competences should the managers responsible for the risk management process have?

- What professional and certified risk management trainings are currently available for managers?

\section{The evolution of managerial functions in the area of risk management}

The emergence of separate job positions responsible for functions related to risk and uncertainty could already be observed at the turn of the 60 s and 70 s of the last century. At that time, in the United Kingdom, the British Safety Council introduced a safety management diploma as a minimum qualification for managerial functions in the field of occupational health and safety. The purpose of introducing a new requirement for managers was to convince enterprises to professionalize safety management. Since then, the training of safety managers has gradually gone beyond the area of occupational health and safety management, evolving towards the formalization of jobs responsible not only for safety management but much more widely - for risk management. In the 1980s, the same institution ran the only certified competence course in Europe in the area of risk management ${ }^{2}$.

At present, enterprises usually decide independently whether the implementation of the risk management function will be in the hands of the top management or whether a specialized job position (in the form of a risk manager or risk specialist) or a new organizational unit (risk management department) will be created. Knight ${ }^{3}$ believes that the appointment of risk managers as separate job positions is not necessary, because risk management should be an area integrated with the general management system, not isolated from its other functions. Thus, risk management should be a competence area not merely for one manager, but for all managers in a given entity. However, in large enterprises, often the international ones, the incorporation of multi-person risk management divisions into the organizational structures can be observed. The implementation of the risk management function in the form of a separate organizational unit requires close cooperation with the main management division and full cohesion with the area of strategic management.

2 B. Crew, Risk Manager - the New Professional, "Industrial Management \& Data Systems" 1982, vol. 82, no. 11/12, pp. 3-30.

3 K.W. Knight, Risk Management is a journey, not a destination, Presentation to the RusRisk/ Marsh ISO 31000 Risk management standard: principle and implementation trends, Seminar, Moscow, 2010, https://fermlab.hse.ru/data/2010/12/16/1208283693/A\%20 Journey\%20 Not\%20A\%20Destination\%20-\%20HO.pdf (accessed: 26.07.2018). 
In addition to placing responsibility for risk management in the organizational structure, the process of the evolution of components of management function in this domain is important. An attempt at chronological mapping is presented in Figure 1.

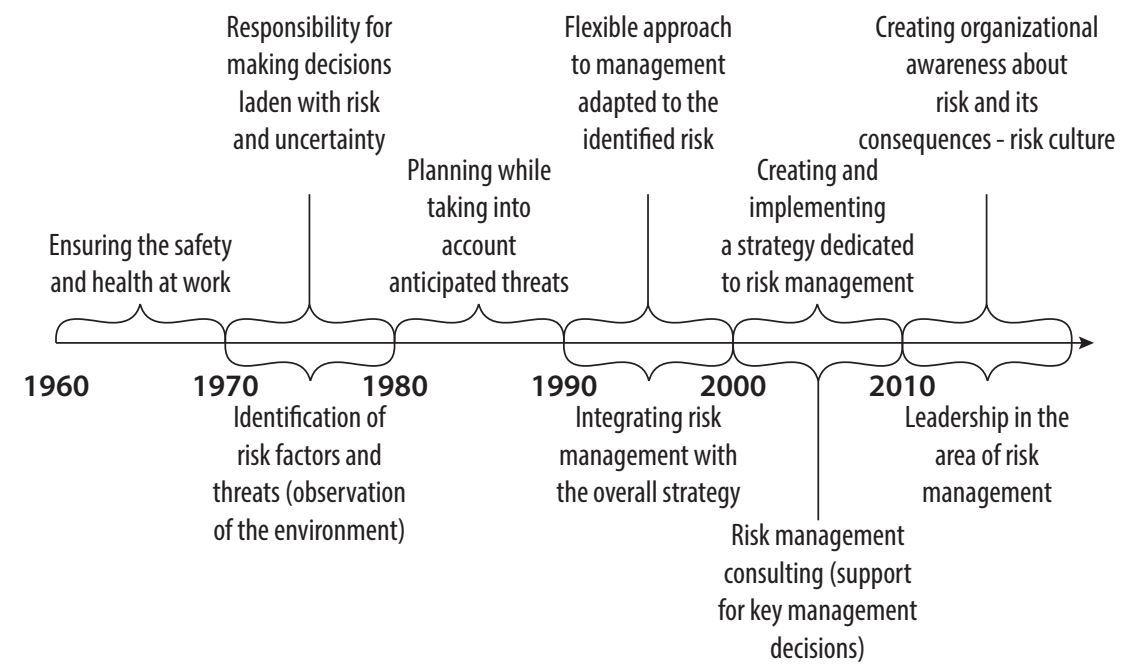

Figure 1 . Components of managerial functions in the area of risk management - the evolution

Source: own study.

As presented in Figure 1, managerial functions in the 1960s were limited to ensuring occupational health and safety 4 . Then, starting from the 1970 s, i.e. the time of intensive development of management methods and concepts ${ }^{5}$, the need to identify risk factors and threats began to be noticed, the process of which resulted in embedding risk and uncertainty within the responsibility of managers making economic decisions ${ }^{6}$. In the next decade, managerial functions in the area of risk management were expanded to include planning processes that took into account anticipated threats in order to eliminate or minimize their negative consequences. At the time, these processes took place at the highest levels of the organizational structure 7 . The 1990 s and the acceleration of globalization processes observed

4 B. Crew, Risk Manager...

5 J. Penc, Nowe koncepcje zarzq̨dzania, "Ekonomika i Organizacja Przedsiębiorstwa” 2002, vol. 7, pp. 3-13.

6 A. Riabacke, Managerial Decision Making Under Risk and Uncertainty, "IAENG International Journal of Computer Science" 2006, vol. 32, no. 4, pp. 1-7.

7 T. Aven, Risk assessment and risk management: Review of recent advances on their foundation, "European Journal of Operational Research" 2016, vol. 253, no. 1, pp. 1-13. 
at the time and the increase in complexity 8 caused the need for a flexible approach to management that took into account the identified risk and ensuring cohesion of actions taken against risk with the overall strategy ${ }^{9}$. The shape of global risk has a number of implications for management ${ }^{10}$. The beginning of the 21 st century can be regarded as the moment of intensification of awareness about the role of risk management in the system of business management, which had an impact on the extension of the scope of managerial functions. This was reflected in the need to formulate separate strategies dedicated to risk management, as well as the need for risk managers to perform advisory functions in supporting key management decisions of top management ${ }^{11}$. In turn, in the second decade of the 21 st century managers are increasingly creating risk-oriented organizational awareness ${ }^{12}$, sometimes called risk culture ${ }^{13}$, and dynamic leadership development in this management domain (risk leaders) ${ }^{14}$.

\section{Functions of managers in the processes of making risky decisions}

Uncertainty and risk are currently becoming key areas of interest for managerial staff due to the scale and intensity of the negative effects that they can cause (financial, functional, personnel). The processes of making decisions laden with uncertainty or risk are therefore embedded into the competence areas of managers and are divided into ${ }^{15}$ :

8 D. Hossu et al., Complex networks to model the economic globalization process, "IFAC Proceedings Volumes" 2009, vol. 42, no. 25, pp. 62-67.

9 F. Schiller, G. Prpich, Learning to organize risk management in organizations: what future for enterprise risk management?, "Journal of Risk Research" 2012, vol. 17, no. 8, pp. 999-1017.

10 P. Jedynak, S. Bąk, The global risk landscape - its shape, tendencies and consequences for management, "Journal of Economics and Management" 2018, vol. 32, no. 2, pp. 48-59.

11 J. Lu, L.C. Jain, G. Zhang, Risk Management in Decision Making, [in:] J. Lu, L.C. Jain, G. Zhang (eds), Handbook on Decision Making. Intelligent Systems Reference Library, vol. 33, Springer, Berlin - Heidelberg 2012.

12 R. Abuzarqa, The Relationship Between Organizational Culture, Risk Management and Organizational Performance, "Cross-Cultural Management Journal" 2019, vol. 21, no. 1, pp. 13-20.

13 I. Gorzeń-Mitka, Leading markers of risk culture in organization, "European Journal of Sustainable Development" 2018, vol. 7, no. 1, pp. 425-434.

14 S. Ertac, M.Y. Gurdal, Deciding to decide: Gender, leadership and risk-taking in groups, "Journal of Economic Behavior \& Organization" 2012, vol. 83, no. 1, pp. 24-30.

15 F.L. Harrison, Decision-making in conditions of extreme uncertainty, "Journal of Management Studies” 1977, vol. 14, no. 2, pp. 169-178; T. Tyszka, Decyzje. Perspektywa psychologiczna i ekonomiczna, Wydawnictwo Naukowe Scholar, Warszawa 2010. 
- making decisions under conditions of certainty (very rare in the case of economic decisions);

- making decisions under conditions of risk (the manager has information that allows forecasting of effects of available alternatives of choice, but these are uncertain effects);

- making decisions in conditions of uncertainty (the manager usually does not have information enabling him to predict the results of available selection options, and if he has them it is not possible to estimate the degree of probability of their occurrence;

- making decisions in conditions of extreme uncertainty (mainly during crises, there is no way for the manager to predict the results of their decisions).

Managers often use a risk matrix to facilitate making decisions laden with a risk or uncertainty. The basic scheme of matrix construction is presented in Figure 2.

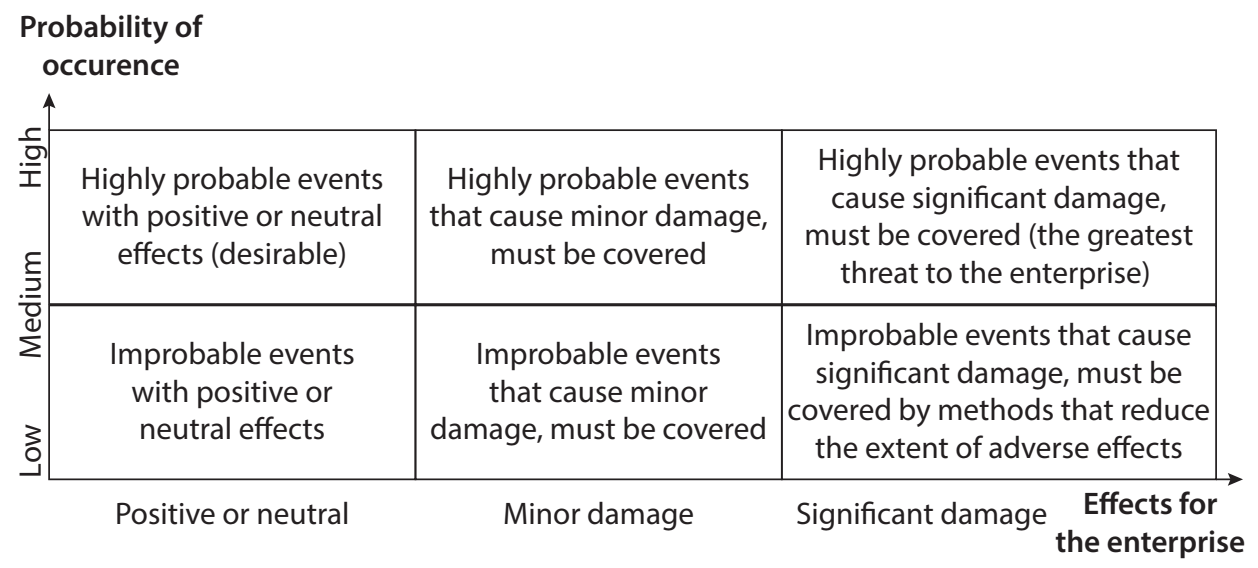

Figure 2. Risk matrix

Source: own study based on A. Panasiewicz, Zarządzanie ryzykiem jako narzędzie podnoszenia wartości firmy, "Zeszyty Naukowe Uniwersytetu Szczecińskiego" 2013, vol. 786, no. 64, pp. 395-402.

According to the risk matrix (Figure 2), the biggest challenge for managers in the area of risk management are decisions regarding highly probable events, whose potential consequences would cause significant damage to the enterprise. However, all events identified as damaging (irrespective of the extent and likelihood of their occurrence) should be included in management decision-making processes.

Despite having managerial skills, errors can occur in decision-making processes that involve risk or uncertainty. The most common managerial errors include ${ }^{16}$ :

16 H.A. Simon, Making Management Decisions: the Role of Intuition and Emotion, "Academy of Management Perspectives" 1987, vol. 1, no. 1, pp. 57-64; L. Coleman, Risk and decision making by finance executives: a survey study, "International Journal of Managerial Finance" 
- errors of holistic assessment - acceptance or rejection of risky actions should not be based on perception formed on intuition;

- lack of rationality of choices made - information necessary to make decisions should not be collected selectively in a subjective way, excluding those that are contrary to personal beliefs;

- focusing solely on profits;

- focusing only on losses;

- wrong decision-making strategies - the managerial mistake is in adopting a strategy which, when assessing a decision, requires referring to the obtained result, not to the expected one.

\section{Managerial competences in the area of risk management}

In addition to making risky decisions, managerial competence is extremely pertinent in the process of risk management. In managerial decisions that involve risk, managers should have the skills to predict economic phenomena. The most commonly used ways to predict economic phenomena in risk management include ${ }^{17}$ :

- assumption of immutability of a given phenomenon on the basis of data on its immutability in past periods;

- observation of changes in a given phenomenon in an upward or downward trend;

- observing cyclically repetitive phenomena, especially when the cycle is repeated several times;

- observing phenomena that constantly cause other phenomena and combining them into sequences of cause and effect;

- observing the analogy of the course of events using models that are a simplified picture of reality;

- estimating the probability of occurrence of specific events.

Another area that is important in the analysis of managerial competences pertains to preferences for taking risky or uncertain decisions that condition new initiatives and actions. Risk-taking is, therefore, a critical variable in understanding

2007, vol. 3, no. 1, pp. 108-124; T. Tyszka, T. Zaleśkiewicz, Racjonalność decyzji. Pewność i ryzyko, Polskie Wydawnictwo Ekonomiczne, Warszawa 2001; E. Jonas et al., Confirmation Bias in Sequential Information Search After Preliminary Decisions, "Journal of Personality and Social Psychology" 2001, vol. 80, pp. 557-571.

17 J. Łuczak, Pewność, niepewność i ryzyko w decyzjach menedżerskich, "Zarządzanie i Finanse" 2012, vol. 10, no. 1, pp. 80-89; A. Magruk, Phenomenon of Uncertainty in the Process of Holistic Anticipation of Non-deterministic Reality, "Procedia Engineering” 2017, vol. 182, pp. 423-442. 
entrepreneurial behaviour. This variable is considered as the basis for making all economic decisions ${ }^{18}$. So, managers with a high-risk preference will be more likely to decide in favour of taking new, risky actions (which can also often bring benefits) than those who prefer low risk and express a fear of potential loss ${ }^{19}$.

Considering the basic set of managerial tasks ${ }^{20}$ :

- making decisions;

- human resource management;

- continuous development and

- adapting the entity to changes in the environment, it appears that the specialized risk management function is closely related to the last task mentioned, and thus the need to adapt the company to the dynamically changing conditions of doing business, which constitutes yet another area of competence for managers.

The competence areas of managers responsible for risk management processes can also be diversified based on the roles they perform in executing their functions - decision-makers, strategy makers, and implementers, planners, creators, analysts, coordinators, advisors, observers, and controllers ${ }^{21}$. On this basis, managers' competences in the area of risk management can be divided as follows:

- creating and implementing risk management strategy;

- planning operations against risk;

- anticipating threats;

- creating awareness of risk factors and threats at all levels of organizational culture;

- analysis of the causes and effects of risk;

- coordinating the integration of the strategy dedicated to risk management with the leading strategy;

- advising the top management;

- observation of the economic environment;

18 C. Mills, K. Pawson, Integrating motivation, risk-taking and self-identity: a typology of ICT enterprise development narratives, "International Small Business Journal” 2012, vol. 30, no. 5, pp. 584-606.

19 S. Barbosa, M. Gerhardt, J. Kickul, The role of cognitive style and risk preference on entrepreneurial self-efficacy and entrepreneurial intentions, "Journal of Leadership \& Organizational Studies" 2007, vol. 13, no. 4, pp. 86-104.

20 B. Nogalski, J. Śniadecki, Umiejętności menedżerskie w zarzq̨dzaniu przedsiębiorstwem, Oficyna Wydawnicza Ośrodka Postępu Organizacyjnego, Bydgoszcz 2001.

21 M. Butterworth, R. Reddaway, T. Benson, Corporate Governance - a guide for insurance and risk managers, Association of Insurance and Risk Management, London 1996; S. Ward, Exploring the Role of the Corporate Risk Manager, "Risk Management: An International Journal" 2001, vol. 3, no. 1, pp. 7-25. 
- constant control of the realization of the risk management strategy.

In addition, risk management is a specialized approach that requires continual updating of knowledge and skills. Therefore, the risk manager/risk specialist/risk officer should not approach the risk analysis arbitrarily but in a flexible, realistic and timely manner, regardless of the importance of the area of activity to which the risk relates ${ }^{22}$. Its main task is to increase the efficiency of the entity's functioning, to prepare it against internal or external threats ${ }^{23}$, as well as to implement actions 24 :

- remedial (against their negative effects);

- preventive (limiting exposure to risk and shaping resilience);

- analytical (used to define risk tolerance limits and make the right decisions).

In addition, the goals and functions of risk managers are also to some extent conditioned by the specificity of a particular business entity (its market position, set of strategic goals or risk management objectives) ${ }^{25}$. Thus, the direction and scope of their work depend on ${ }^{26}$ :

- contextual factors;

- the influence of top management;

- external influences;

- characteristics of the enterprise;

- the level of development of the enterprise;

- sectoral risk factors.

\section{Analysis of the availability of professional trainings in risk management}

Currently, there is a whole range of specialized training offers available, concluding with obtaining certified titles: Risk Manager, Risk Management Specialist, Chief Risk Officer - CRO (the highest level of professional specialization in the area of risk management). Undergoing this type of training can be extremely helpful in performing managerial functions in the area

22 E. Finch, Risk and the Facilities Manager, "Facilities" 1992, vol. 10, no. 4, pp. 10-13.

23 I. Staniec, Uwarunkowania skuteczności zarzq̨dzania ryzykiem w organizacjach, "Zeszyty Naukowe Politechniki Łódzkiej” 2011, vol. 1099, pp. 184-195.

24 L.L. Colquitt, R.E. Hoyt, R.B. Lee, Integrated Risk Management and the Role of the Risk Manager, "Risk Management and Insurance Review" 2008, vol. 2, no. 3, pp. 43-61.

25 P. Jedynak, S. Bąk, Objectives of Risk Management in the Financial Services Sector - the Perspective of Polish Enterprises Listed on the Warsaw Stock Exchange, "Journal of Emerging Trends in Marketing and Management” 2019, vol. 1, no. 1, pp. 231-240.

26 S. Ward, Exploring the Role... 
of risk management. The trainings are offered by international organizations and associations consociating managers responsible for risk management in enterprises, representatives of the public sector, theoreticians, researchers, and trainers. Leading organizations of this type include in the world: FERMA (Federation of European Risk Management Associations based in Brussels, POLRISK is a member of FERMA), AIRMIC (Association of Insurance and Risk Managers in Industry and Commerce, UK), ARIMI (Asia Risk Management Institute in Singapore), GARP (Global Association of Risk Professionals), PRMIA (Professional Risk Managers' International Association), RIMS (Risk and Insurance Management Society).

The most prestigious offers of professional and certified training, enabling the acquisition of specialist knowledge and skills necessary to perform managerial functions in risk management are presented in Table 1.

Table 1. Professional trainings for managers in the area of risk management

\begin{tabular}{|c|c|c|}
\hline Institution & Name of training & Main content of the training \\
\hline PRMIA & $\begin{array}{l}\text { PRM (Professional } \\
\text { Risk Manager) }\end{array}$ & $\begin{array}{l}\text { 1. Finance theory, financial instruments, financial markets. } \\
\text { 2. The mathematical basis of risk measurement. } \\
\text { 3. Risk management practices. } \\
\text { 4. Case studies and risk management standards, legal } \\
\text { requirements, best practices, ethics, regulations. }\end{array}$ \\
\hline PRMIA & $\begin{array}{l}\text { ORM (Operational } \\
\text { Risk Manager } \\
\text { Certificate) }\end{array}$ & $\begin{array}{l}\text { 1. The role of risk management in the post crisis financial } \\
\text { services industry } \\
\text { 2. Relationships within risk management and corporate } \\
\text { governance } \\
\text { 3. Different roles in risk governance } \\
\text { 4. Theory and process of risk management } \\
\text { 5. Development of risk management with an introduction } \\
\text { to the area of risk culture } \\
\text { 6. Operational risk assessment program }\end{array}$ \\
\hline FERMA & $\begin{array}{l}\text { RIMAP (European } \\
\text { Risk Management } \\
\text { Professional } \\
\text { Certification) }\end{array}$ & $\begin{array}{ll}\text { 1. } & \text { Essentials and requirements of risk management } \\
\text { 2. } & \text { Risk assessment } \\
\text { 3. } & \text { Risk treatment I (basic module) } \\
\text { 4. } & \text { Risk treatment II (advanced module) }\end{array}$ \\
\hline RIMS & $\begin{array}{l}\text { RIMS-CRMP } \\
\text { (Certified Risk } \\
\text { Management } \\
\text { Professional) }\end{array}$ & $\begin{array}{l}\text { 1. Analysis of business models } \\
\text { 2. Designing organizational strategies against risk } \\
\text { 3. Implementation of the risk management process } \\
\text { 4. Developing managerial competences in the area of risk } \\
\text { 5. Risk management as support for decision-making } \\
\text { processes }\end{array}$ \\
\hline
\end{tabular}


Table 1 (continued)

\begin{tabular}{|c|c|c|}
\hline Institution & Name of training & Main content of the training \\
\hline ARIMI & $\begin{array}{l}\text { Certified Enter- } \\
\text { prise - wide Risk } \\
\text { Manager } \\
\text { (ARIMI-CERM) }\end{array}$ & $\begin{array}{l}\text { Risk CHAMPIONS Master Class - Leading ERM Projects for Your } \\
\quad \text { Organization: } \\
\text { 1. Designing: Risk Management Frameworks, } \\
\text { Systems \& Culture } \\
\text { 2. Implementing: Systems Change \& Nurturing } \\
\text { a Risk-Aware Culture } \\
\text { 3. Sustaining: Managing Changes, Crises \& Business } \\
\text { Sustainability } \\
\text { 4. Risk PROFESSIONALS - Managing the ERM Function } \\
\text { in Organizations: } \\
\text { 5. Corporate Reputation \& Stakeholders Risk Management } \\
\text { 6. Corporate Governance \& Enterprise Risk Management } \\
\text { 7. Corporate Ethics, Fraud \& Compliance Risk Management } \\
\text { 8. Corporate Control, Internal Audit \& Risk Management } \\
\text { 9. Corporate Performance \& Human Capital Risk } \\
\text { Management }\end{array}$ \\
\hline ARIMI & \begin{tabular}{|l} 
Certified \\
Professional Risk \\
Managers \\
(ARIMI-CPRM)
\end{tabular} & $\begin{array}{l}\text { Risk LEADERS Master Class - The Essentials of Risk \& Value } \\
\text { Management: } \\
\text { 1. Risk-Taking \& Value Creation Management } \\
\text { in Organizations - Principles, Theory \& Practices } \\
\text { 2. Business Ethics, Social Responsibility \& Corporate Value } \\
\text { Sustainability } \\
\text { 3. Innovation, Change \& Project Risk Management } \\
\text { 4. Risk EXPERTS Master Class - Mastering the Process for } \\
\text { Managing Risk \& Value: } \\
\text { 5. Risk Assessment \& Corporate/Project Value Profile } \\
\text { Diagnostic } \\
\text { 6. Risk Learning, Communication \& Decision Making } \\
\text { 7. Risk Control \& Business Continuity Management } \\
\text { 8. Risk Financing \& Transfer Solutions } \\
\text { 9. KRIs/KPIs Dashboard: Risk Monitoring, Reporting \& } \\
\text { Improvement }\end{array}$ \\
\hline GARP & \begin{tabular}{|l|} 
Financial Risk \\
Manager (FRM)
\end{tabular} & $\begin{array}{l}\text { 1. Financial markets and products } \\
\text { 2. Basics of risk management } \\
\text { 3. Quantitative analysis } \\
\text { 4. Valuation and risk models } \\
\text { 5. Market risk, credit risk, and operational risk } \\
\text { 6. Risk and investment management } \\
\text { 7. } \text { Current events in financial markets } \\
\end{array}$ \\
\hline
\end{tabular}




\begin{tabular}{|l|l|ll|}
\hline Institution & Name of training & \multicolumn{1}{c|}{ Main content of the training } \\
\hline AIRMIC & Risk Leadership & 1. & Organizational and personal leadership \\
& Programme & 2. & Transformation - from risk manager to risk leader \\
& & 3. & Improving the leader \\
& & 4. The importance and profile of risk management \\
& & 5. & Cyber cooperation \\
& & 6. & Strategic decision making \\
& &
\end{tabular}

Source: own study based on: RIMS-CRMP, Examination, Risk and Insurance Management Society, 2018, https://www.rims.org/certification/rims-crmp/exam-content (accessed: 26.07.2018); FERMA RIMAP, European Risk Management Professional Certification, 2018, https://www.ferma.eu/rimap-cer tification/ (accessed: 26.07.2018); PRMIA PRM, Exam Preparation Resources, 2018, https://www.prm ia.org/Public/Certificates/APRM_/Public/Certificate/What_is_the_Associate_PRM_Certificate.as px?hkey=975a69ef-9685-4033-98b8-cf8e79582fc6 (accessed: 26.07.2018); PRMIA ORM, Operational Risk Manager Certificate, 2019, https://www.prmia.org/Public/Certificates/ORM/Public/Certificate /ORM.aspx?hkey=b709c408-754f-4162-a5b1-cacbea83a592 (accessed: 7.12.2019); GARP FRM, The global standard for financial risk, 2019, https://www.garp.org/\#!/frm (accessed: 7.12.2019); AIRMIC, Risk Leadership Programme with Cass Business School, 2019, https://www.airmic.com/leadership (accessed 7.12.2019); ARIMI CERM, Certified Enterprise-wide Risk Manager, 2019, https://arimi.org /certified-enterprise-wide-risk-manager/ (accessed: 7.12.2019); ARIMI CPRM, Certified Professional Risk Manager, 2019, https://arimi.org/certified-professional-risk-manager/ (accessed: 7.12.2019).

Based on the analysis of the content of professional training (Table 1), several main areas of requirements for positions of risk managers can be outlined ${ }^{27}$ :

- theoretical knowledge of risk management;

- so-called global awareness (macroeconomic knowledge);

- analytical skills;

- knowledge of the sector and the market;

- negotiation and communication skills;

- strategic thinking;

- knowledge of legal regulations;

- ethical principles;

- ability to work in cyberspace.

In addition, the review indicates that the trainings offered can be divided into: comprehensive (offering training content for risk managers, regardless of sector and business profile) and specific (dedicated e.g. to financial or operational risk management).

27 A. Caldas, 10 Must Have Skills to be a Successful Risk Manager, https://riskmanagementguru .com/10-must-skills-successful-risk-manager.html/ (accessed: 25.07.2018). 


\section{Conclusions}

Summing up the considerations that are the subject of this work, it managed to get answers to all of the research questions. Thus, becoming familiar with the evolution of managerial functions in the area of risk management, as well as developing a catalog of managerial competences in this area of management, enabled the identification of the role of managers in contemporary enterprise risk management.

The research limitation was the fact that the analyses were performed solely on the basis of literature analysis and training offers for risk managers. Therefore, future analyses should focus on empirical research in various groups of enterprises, enabling verification whether the competences required for risk managerial positions are in fact held by persons performing these functions and whether risk managers have qualifications confirmed by appropriate, professional trainings.

\section{References}

Abuzarqa R., The Relationship Between Organizational Culture, Risk Management and Organizational Performance, "Cross-Cultural Management Journal" 2019, vol. 21, no. 1, pp. 13-20.

AIRMIC, Risk Leadership Programme with Cass Business School, 2019, https://www.airmic.com /leadership (accessed 7.12.2019).

ARIMI CERM, Certified Enterprise-wide Risk Manager, 2019, https://arimi.org/certified-enterprise -wide-risk-manager/ (accessed: 7.12.2019).

ARIMI CPRM, Certified Professional Risk Manager, 2019, https://arimi.org/certified-professional -risk-manager/ (accessed: 7.12.2019).

Aven T., Risk assessment and risk management: Review of recent advances on their foundation, "European Journal of Operational Research" 2016, vol. 253, no. 1, pp. 1-13.

Barbosa S., Gerhardt M., Kickul J., The role of cognitive style and risk preference on entrepreneurial self-efficacy and entrepreneurial intentions, "Journal of Leadership \& Organizational Studies" 2007, vol. 13, no. 4, pp. 86-104.

Butterworth M., Reddaway R., Benson T., Corporate Governance - a guide for insurance and risk managers, Association of Insurance and Risk Management, London 1996.

Calandro J., A leader's guide to strategic risk management, "Strategy \& Leadership" 2015, vol. 43, no.1, pp. 26-35.

Caldas A., 10 Must Have Skills to be a Successful Risk Manager, https://riskmanagementguru.com /10-must-skills-successful-risk-manager.html/ (accessed: 25.07.2018).

Coleman L., Risk and decision making by finance executives: a survey study, "International Journal of Managerial Finance" 2007, vol. 3, no. 1, pp. 108-124.

Colquitt L.L., Hoyt R.E., Lee R.B., Integrated Risk Management and the Role of the Risk Manager, "Risk Management and Insurance Review" 2008, vol. 2, no. 3, pp. 43-61.

Crew B., Risk Manager - the New Professional, "Industrial Management \& Data Systems" 1982, vol. 82, no. 11/12, pp. 3-30.

De Loach J., The new risk imperative - an enterprise - wide approach, "Handbook of Business Strategy" 2004, vol. 5, no. 1, pp. 29-34. 
Elahi E., Risk management: the next source of competitive advantage, "Foresight" 2013, vol. 15, no. 2, pp. 117-131.

Ertac S., Gurdal M.Y., Deciding to decide: Gender, leadership and risk-taking in groups, "Journal of Economic Behavior \& Organization" 2012, vol. 83, no. 1, pp. 24-30.

FERMA RIMAP, European Risk Management Professional Certification, 2018, https://www.ferma .eu/rimap-certification/ (accessed: 26.07.2018).

Finch E., Risk and the Facilities Manager, "Facilities" 1992, vol. 10, no. 4, pp. 10-13.

GARP FRM, The global standard for financial risk, 2019, https://www.garp.org/\#!/frm (accessed: 7.12.2019).

Gorzeń-Mitka I., Leading markers of risk culture in organization, "European Journal of Sustainable Development" 2018, vol. 7, no. 1, pp. 425-434.

Harrison F.L., Decision-making in conditions of extreme uncertainty, "Journal of Management Studies" 1977, vol. 14, no. 2, pp. 169-178.

Hossu D., Humaila H., Mocanu S., Saru D., Complex networks to model the economic globalization process, "IFAC Proceedings Volumes" 2009, vol. 42, no. 25, pp. 62-67.

Jedynak P., Bąk S., Objectives of Risk Management in the Financial Services Sector - the Perspective of Polish Enterprises Listed on the Warsaw Stock Exchange, "Journal of Emerging Trends in Marketing and Management" 2019, vol. 1, no. 1, pp. 231-240.

Jedynak P., Bąk S., The global risk landscape - its shape, tendencies and consequences for management, "Journal of Economics and Management" 2018, vol. 32, no. 2, pp. 48-59.

Jonas E., Schulz-Hardt S., Frey D., Thelen N., Confirmation Bias in Sequential Information Search After Preliminary Decisions, "Journal of Personality and Social Psychology" 2001, vol. 80, pp. 557-571.

Knight K.W., Risk Management is a journey, not a destination, Presentation to the RusRisk/Marsh ISO 31000 Risk management standard: principle and implementation trends, Seminar, Moscow, 2010, https://fermlab.hse.ru/data/2010/12/16/1208283693/A\%20Journey\%20Not\%20 A\%20Destination\%20-\%20HO.pdf (accessed: 26.07.2018).

Lu J., Jain L.C, Zhang G., Risk Management in Decision Making, [in:] J. Lu, L.C. Jain, G. Zhang (eds), Handbook on Decision Making. Intelligent Systems Reference Library, vol. 33, Springer, Berlin - Heidelberg 2012.

Łuczak J., Pewność, niepewność i ryzyko w decyzjach menedżerskich, "Zarządzanie i Finanse" 2012, vol. 10, no. 1, pp. 80-89.

Magruk A., Phenomenon of Uncertainty in the Process of Holistic Anticipation of Non-deterministic Reality, "Procedia Engineering" 2017, vol. 182, pp. 423-442.

Mills C., Pawson K., Integrating motivation, risk-taking and self-identity: a typology of ICT enterprise development narratives, "International Small Business Journal" 2012, vol. 30, no. 5, pp. 584-606.

Nogalski B., Śniadecki J., Umiejętności menedżerskie w zarzq̨dzaniu przedsiębiorstwem, Oficyna Wydawnicza Ośrodka Postępu Organizacyjnego, Bydgoszcz 2001.

Panasiewicz A., Zarzqdzanie ryzykiem jako narzędzie podnoszenia wartości firmy, "Zeszyty Naukowe Uniwersytetu Szczecińskiego” 2013, vol. 786, no. 64, pp. 395-402.

Penc J., Nowe koncepcje zarządzania, "Ekonomika i Organizacja Przedsiębiorstwa” 2002, vol. 7, pp. 3-13.

PRMIA ORM, Operational Risk Manager Certificate, 2019, https://www.prmia.org/Public/Certifi cates/ORM/Public/Certificate/ORM.aspx?hkey=b709c408-754f-4162-a5b1-cacbea83a592 (accessed: 7.12.2019).

PRMIA PRM, Exam Preparation Resources, 2018, https://www.prmia.org/Public/Certificates/AP RM_/Public/Certificate/What_is_the_Associate_PRM_Certificate.aspx?hkey=975a69ef-96 85-4033-98b8-cf8e79582fc6 (accessed: 26.07.2018). 
Riabacke A., Managerial Decision Making Under Risk and Uncertainty, "IAENG International Journal of Computer Science" 2006, vol. 32, no. 4, pp. 1-7.

RIMS-CRMP Examination, Risk and Insurance Management Society, 2018, https://www.rims.org /certification/rims-crmp/exam-content (accessed: 26.07.2018).

Schiller F., Prpich G., Learning to organize risk management in organizations: what future for enterprise risk management?, "Journal of Risk Research" 2012, vol. 17, no. 8, pp. 999-1017.

Simon H.A., Making Management Decisions: the Role of Intuition and Emotion, "Academy of Management Perspectives" 1987, vol. 1, no. 1, pp. 57-64.

Staniec I., Uwarunkowania skuteczności zarzq̨dzania ryzykiem w organizacjach, "Zeszyty Naukowe Politechniki Łódzkiej" 2011, vol. 1099, pp. 184-195.

Tyszka T., Decyzje. Perspektywa psychologiczna i ekonomiczna, Wydawnictwo Naukowe Scholar, Warszawa 2010.

Tyszka T., Zaleśkiewicz T., Racjonalność decyzji. Pewność i ryzyko, Polskie Wydawnictwo Ekonomiczne, Warszawa 2001.

Ward S., Exploring the Role of the Corporate Risk Manager, "Risk Management: An International Journal" 2001, vol. 3, no. 1, pp. 7-25.

\section{Abstract}

Management staff now face not so much a choice, but the necessity to implement a new management function, which is risk management. The purpose of this text is to identify the role of a manager in contemporary enterprise risk management. To achieve the intended objective, the evolution of the development of managerial functions in the area of risk management is presented, a catalogue of competences necessary to perform such functions is also presented along with a review of currently offered professional trainings which authorize the performance of the functions of risk managers, risk management specialists, and risk officers.

Keywords: manager, risk, risk management 